\title{
THE PRESERVATION OF THE ASIAN-AFRICAN CONFERENCE MUSEUM LIBRARY COLLECTIONS
}

\author{
Nurul Oktavia* \& Samson CMS*
}

\author{
*Universitas Padjadjaran, Bandung \\ Email: nurul16044@mail.unpad.ac.id, samson.cms@unpad.ac.id \\ (Submitted: 03-11-2019, Revised: 23-03-2020, Accepted: 01-02-2021) \\ DOI: 10.24252 /v9i1a7
}

\begin{abstract}
ABSTRAK: Museum Konferensi Asia Afrika memiliki perpustakaan khusus yang menyimpan berbagai koleksi langka, khususnya koleksi mengenai pelaksanaan Konferensi Asia Afrika 1955. Penelitian ini bertujuan untuk menggambarkan pelestarian yang dilakukan perpustakaan pada koleksi langka tersebut. Penelitian ini bertujuan untuk mengetahui uapaya pelestarian koleksi yang dilakukan oleh Perpustakaan Museum Konferensi Asia Afrika. Metode penelitian yang digunakan adalah kualitatif deskriptif. Pengumpulan data menggunakan teknik observasi, wawancara dengan staf Museum Konferensi Asia Afrika, dan kajian pustaka. Hasil penelitian menunjukkan bahwa Perpustakaan Museum Konferensi Asia Afrika telah melakukan upaya pelestarian koleksi dengan cara membatasi pengunjung yang masuk ke ruang koleksi, pembersihan debu menggunakan vacuum cleaner, penggunaan rak yang sesuai standar, bekerjasama dengan Perpustakaan Nasional Republik Indonesia dalam restorasi, hingga menerapkan larangan pengunjung membawa makanan/minuman ke ruang perpustakaan. Namun demikian, masih banyak upaya yang perlu diterapkan dan dioptimalkan lagi seperti kontrol temperatur dan kelembapan udara, cahaya, polusi, pencegahan serangga dan jamur, hingga antisipasi bencana alam. Peran pustakawan sangat dibutuhkan untuk mengoptimalkan upaya pelestarian koleksi di Perpustakaan Museum Konferensi Asia Afrika.
\end{abstract}

Kata kunci: Koleksi langka perpustakaan; pelestarian koleksi; perpustakaan musium

ABSTRACT: The Asian-African Conference Museum owns a special library that has stored a variety of rare collections, especially collections on the holding of the 1955 Asian African Conference. This study aims to describe the preservation carried out by the library for those rare collections. The research used a descriptive qualitative method. The data were obtained through interviews with the staff of the Asian-African Conference Museum Library, and literature studies. The result showed that the Asian African Conference Museum Library had preserved the collection by limiting visitors to the collection room, cleaning the dust using a vacuum cleaner, using shelves according to standards, cooperating with the National Library of the Republic of Indonesia in restoration, and implementing a ban on visitors carrying food/drink to the library. However, there were still many efforts that need to be implemented and optimized such as temperature and humidity control, lighting, pollution, prevention of insects and fungi, and anticipate natural disasters. The role of the librarian is needed to optimize the preservation of collection efforts in the Asian-African Conference Museum Library.

Keywords: Library rare collections; library preservation; museum library

\section{INTRODUCTION}

The Law of the Republic of Indonesia Number 43 of 2007 concerning Library, in Article 3 states that "the library functions as media for education, research, preservation, information, and recreation to educate and empower the Nation". These functions are very important and should be 
implemented in all types of libraries, including special libraries. Every special library has owned materials that are classified as rare and special. These rare and special library collections may only be owned by the library itself, no somewhere else. Thus, to maintain and care for such kind collections, it is necessary to implement library collection preservation activities so the collections are maintained for a long time.

One of the special libraries that have stored rare collections in Indonesia is the Asian-African Conference Museum Library, which is located in Bandung, West Java. This library has collections regarding all the events of the Asian-African Conference which has been held so far. The collections are historic collections that are possibly stored in the Asian-African Conference Museum Library. The library has a great responsibility to preserve its rare collections due to the collections are rare and very important as historical evidence for Indonesian people, particularly for Indonesian foreign policy related to the Asian-African Conference events. The collections are expected to become historical evidence to the present and future generations, thus providing and preserving that nation's history is an obligation. Therefore, the library collections must be gently treated so that their physical condition and the information contained remain sustainable.

Based on the explanation above, preservation as of library functions needs to be optimally implemented for the sake of the preservation of the collection. Preservation refers to that the library carries out preservation, conservation, and restoration activities on the collections or library materials owned by the library. In addition to keeping the collection maintain for future generations, the rare collections within the library have also become supporting documents for researchers and other parties related to the Asian-African Conference from time to time. This research is expected to be a reflection of collection preservation activities at the Asian-African Conference Museum Library and is expected might be useful, developed, and optimized by other special libraries, more particularly in museum libraries.

\section{PREVIOUS FINDINGS}

In the same Law mentioned above, Article 1 defines library as "institutions that manage collections of written works, printed works, and/or recorded works in a professional manner with a standard system to meet the educational, research, preservation, information, and recreational needs of the patrons". One type of library is a special library which is a library that is limited to the end-users in government institutions, community institutions, religious educational institutions, houses of worship, or other organizations. Every library owned its reading materials, and every library must preserve each of these materials, as is one of the library functions previously mentioned, especially when the collections are rare.

Fatmawati (2018) said the purpose of preserving library collections is more on saving the information values contained in a document, accelerating the search and acquisition of information, maintaining aspects of the beauty and tidiness of documents, maintaining library materials so that they can be used for the long term, and preventing collections from various factors that can damage the collections. Preservation of library collections, according to Martoadmojo (1994), has the following functions:

1. Protection: protect and prevent damage to library materials

2. Maintenance: extend the life of library materials

3. Health: related to hygiene which will affect human health

4. Educational: encouraging librarians and users to learn to preserve library materials

5. Social: to train patience, especially librarians and users in preserving library materials

6. Economic: long-term preservation will save finance

7. Beauty: good condition of library materials will create the beauty of the library

Preservation is more comprehensive regarding the preservation of collections in the library. There are more specific forms of preservation, namely conservation and restoration. Conservation itself contains activities that specifically carry out preservation, prevention, and maintenance. Restoration is more about repairing collections whose condition has been damaged. 
Several factors of damage to library materials need to be considered. According to Fatmawati (2017), these factors are divided into two, namely internal and external factors. Internal factors could be caused by the materials themselves, for example, the acid compounds in the materials (papers), the high and low temperatures within the library, the strength and weakness of the light that hits the collections. For paper materials, the age of the materials has also affected their durability. Besides, the ink used in the paper can also affect the durability of the collection. Meanwhile, the external factors could be as follows:

\section{Environmental}

\section{Air Temperature and Humidity}

Temperature is inversely proportional to humidity. That is, the higher the temperature the lower the humidity. Vice versa, the lower the temperature the higher the humidity. High and low temperature and humidity will affect the condition of library collections. Important to note here is the water vapor content in the air, or what is called relative humidity (RH). Relative humidity below $30 \%$ is estimated to be dangerous because it results in drying of the material so that it becomes brittle, whereas if the relative humidity is above $75 \%$ it is also not good because it allows the growth of fungi and biota. Ideally, the temperature conditions for the library collection room are around $20-24^{\circ} \mathrm{C}$ and the humidity should be in the range of around $45-60 \%$ RH (Fatmawati, 2017).

Air temperature and humidity have little effect on the physical condition of the collection, with a stable record. If there are fluctuations or changes in the ups and downs of the air conditions, it will greatly affect the collections. Therefore, the air within the library must always be stable. To create a stable air condition, an air conditioner and a thermometer might be useful to measure the temperature in the library room and a hygrometer to measure the relative humidity of the air.

\section{Air Pollution}

All pollutants might also damage library collections. Examples of air pollution are sulfur dioxide gas, hydrogen sulfide gas, nitrogen oxide gas originating from combustion products (eg combustion of motor vehicles and factories). These gases can react with oxygen and water vapor in the air and could form acidic compounds that can damage the collections. Libraries need to be equipped with an air cleaner. Another example of pollution that is most often found in the library is dust. Usually, dust is easy to stick to the collections, particularly those collections placed in the open space. To remove dust from the collections, the librarian needs to use a damp cloth to clean the dust on the collection. It is not recommended to use a duster, because the duster will make the dust fly even more. Some collections also need to be stored in glass-covered displays so they are covered from dust.

\section{Lighting}

The light that is meant here is sunlight and lamplight. The light can cause lignin in paper to react with other components so that the color of the paper becomes pale and can fade the ink. In addition, Ulta Violet (UV) radiation in light is also capable of causing photochemical reactions that can damage the collection. The light must be adjusted properly. Therefore, we need capable tools for measuring light or what is called a lux meter. According to Fatmawati $(2017: 114)$ that "good lighting for library collections is 40 lux".

\section{Library Shelves}

Library shelves or library collection cabinets that do not meet the requirements are also a factor in damaging the collections. Once a large book stores on a small shelf, it would damage the physical condition of the book. The library must provide shelves that meet the standards with the following criteria: according to the size of the book or collection; there is strong support; anti-rust; blunttipped, and shelf height from the floor at least $5-6 \mathrm{~cm}$ to avoid termites. In addition, the way the book is arranged also affects the physical condition of the book. If the books are arranged with a 
distance that is too narrow, it will be difficult to retrieve so that the user/officer who wants to take the book will take the book by force. It might result in physical damage to the book. Books that are spaced too loosely will also create a lot of space and seem untidy. Therefore, the library shelving must be done properly.

\section{Natural disasters}

Floods, earthquakes, landslides, tsunami, volcanic eruptions, storms, hurricanes, and other natural disasters cannot be predicted when they will come. Natural disasters are the only damage factor that cannot be prevented but they can still be anticipated. One of the anticipations that need to be done is to design a building or library building with attention to safety. There should be safety signs in every room. Librarians must also have knowledge and understanding about disaster rescues.

\section{Biotas}

Damages caused by biotas are called biodeterioration. Biota is a big enemy of librarians because many library collections are also damage caused by biotas. The biotas here are fungi, insects (ants, booklice, cockroaches, termites, silverfish, bookworms), rodents (rats), to biological substances (mosses and bacteria). One of the factors that invite the presence of this destructive biota is the cleanliness of the library room. Leftovers or food wrappers can trigger insects. In addition, humid room conditions, lack of lighting, and dust can also invite biota life in the library. Insects and mice usually leave droppings on the collection. Sometimes some eat paper or even use it for nesting. Therefore, the cleanliness of the library space must be considered. Fumigation should also be carried out periodically, especially on new books that have not been processed. This is done to prevent the growth of fungus. In addition, putting camphor in several corners of the room can also help prevent insects from coming.

\section{Humans}

Humans as library users often not paying more attention to how to use and care for the library collection that is used. For example, marking a page by folding it; leave the book open after reading it; make a book as a base; opening the page with saliva; folding books when read; eat and drink while reading; vandalism; mutilation; or eliminating books (Fatmawati 2017). These habits must be changed, one of which is by providing socialization to the users.

\section{RESEARCH METHODOLOGY}

This descriptive qualitative research used a case study approach. A case study is an in-depth study of an individual, a group, an organization, an activity program, and so on. The goal is to obtain a complete and in-depth description of an entity (Rahardjo 2010). This method was chosen because the research will discuss an activity which is collection preservation carried out by several individuals in the library. The data were obtained through observation, interviews, and literature review. The interviews were conducted only with a librarian on duty in this library. The observations were carried out for approximately one month. The literature reviews were carried out to increase the researcher's insight regarding the activities of preserving library collections.

\section{RESULTS AND FINDINGS}

Preservation of library collections is one of the important duties that the Asian-African Conference Museum Library has maintained. The library's collections of the history of the Asian-African Conference are rare and difficult to find in other libraries. Hence, the collections are important assets of the library, as well as for the Indonesian people. The contents of the collections contain valuable historical evidence for the Indonesian people. The following will describe the preservation of rare collections in this library.

\section{Internal Factors}


The quality of the basic materials for each library collection cannot be separated from the durability or age of the collection. The better the quality used, the longer the life of a collection. Apart from the basic material of manufacture which is difficult to know, age is an internal factor that might cause damage to the library collections. The museum library houses various collections in the form of old books. Many books are decades. Old collections are generally fragile. The library stores important old books in glass displays. Some old newspaper clippings have also been converted to digital form. The library, which is under supervised by the Ministry of Foreign Affairs of the Republic of Indonesia also collaborates with the National Library of the Republic of Indonesia to restore collections whose physical condition has been damaged, such as books whose covers have come off, parts of the contents of books that have torn paper, books whose paper has come off of them. the volume, and so on

\section{External Factors}

\section{Environmental Factors}

\section{a) The temperature and humidity}

The room of the Asian-African Conference Museum Library is equipped with air conditioning. It is to make the room temperature stable. As previously explained, the ideal library room temperature is around $20-24^{\circ} \mathrm{C}$. In the library collection room, the air conditioner is always on, but the details of the high and low temperatures are unknown, either is set properly or not. Even in the reading room, the air conditioner should always be on. However, due to the condition of the officers who did not allow to be exposed to air conditioning, the air conditioner was turned off. In addition, even if the air conditioning is turned on, the temperature is not set accordingly. It is because at certain times the officers turn on the air conditioner with a temperature without definite provisions. Therefore, the temperature needs to be considered. In addition, it is also necessary for the library room to be equipped with a hygrometer to properly set the humidity of the air.

\section{b) Air pollution}

The library collection rooms are very dusty, as observed. Every morning, the library staff cleaned the dust using a feather duster. This way is not correct because it cannot get rid of the dust from the books, but it makes it fly even more. It would be better if the staff used a wet cloth to clean because the dust will stick to the wet cloth. Every Friday, The dust was swept by a vacuum cleaner. This step is quite appropriate because the vacuum cleaner can suck the dust. As suggested, it would be much better if the frequency of using the vacuum cleaner was increased, for example, three times a week. In addition, the range areas are further expanded to include the whole space in the library. Some collections are equipped with plastic covers to avoid dust adhering directly to the collection. Some rare collections are placed in glass displays so that the collection is safe from dust. Dust is one of the most common problems in the library. Apart from being able to damage the collections, dust is also harmful to human health, especially the respiratory system. Therefore, the staff needs to pay attention to the cleanliness of the room.

\section{c) Illumination}

The library used lamplight to lighten the rooms. It would be better if the light conditions were measured using a lux meter. The library room light that is too bright is not good for collections. The library lighting that is too dim is also not good for users. Fatmawati (2017:144) states that good lighting for the library room is 40 lux. In addition, the library room also needs to be equipped with an ultraviolet filter.

\section{d) Library Shelves}

The library shelves provide are quite good and meet the requirements but the shelving seems quite improper. One of the reasons is the existence of books that are too large, so they cannot be put on the shelves. The books are deliberately laid down with the reason to stay in the right classification line. However, it causes untidy storage. In addition, there are books on the shelves 
that are too full so the books are difficult to take. It can result in coercion when picking up the book, and it may cause physical damage to the book. Problems in shelving are also found in the unavailability of places for visitors to put their recently read collections. This makes it possible for visitors to enter the collection in any place (not according to library classification). It causes many books to be tucked away and not in their proper places, making them difficult to find.

\section{e) Natural disasters}

Natural disasters are one of the factors that cannot be prevented and it is difficult to know when they will come. The library has provided fire extinguishers and posted signs of evacuation routes in anticipation of a disaster. The signs affixed are arrow stickers that point to the emergency exits leading to the outside of the museum building. However, things related to disaster anticipation at the library should be optimized, for example by increasing disaster literacy for the library staff. Disaster literacy is expected to be able to assist the staff in saving library collections and saving themselves and library visitors when a disaster occurs.

\section{2) Biotas}

The library has carried out fumigation to protect the room from insects. However, the fumigation activities are not routine and the time is uncertain. Sometimes once a month, once every two months. This is due under the authority of the Ministry of Foreign Affairs of the Republic of Indonesia. The fumigation is carried out by a special officer ordered from the center and imported from Jakarta. Other things need to be considered to prevent biota life. One of them is maintaining the cleanliness of the room (housekeeping). The condition of the collection room in the library is too dusty, as explained. The temperature and humidity of the air are also not fully considered, and air pollutants can invite biota life. With dusty conditions, the library collections will be susceptible to attack by biotas such as fungi and insects.

\section{3) Humans}

The preservation activities at this museum library can still be optimized further. One of the causes of the existing deficiencies is the unavailability of expert librarians in the library. There were only museum officers on duty in the library. This of course causes the service provided to be not optimal in the library. To prevent damage to collections caused by humans, in this case, library visitors, there is a policy that requires every visitor who wants to enter the collection room to show their identity card to the staff. They must also fill out the visitor list completely and correctly. In addition, those who enter the collection room must be accompanied by an officer. Apart from the safety factor, this is also expected to reduce the possibility of lost books. Another policy is that library visitors are not allowed to bring food or drinks into the library.

\section{CONCLUSION}

The Asian-African Conference Museum Library has made several efforts to preserve library collections, such as placing old collections or rare collections in glass displays, using standard shelves, using a vacuum cleaner to clean dust, fumigation, and monitoring visitors in the collection room. However, there are still many conservation efforts that need to be optimized, such as temperature and humidity control, the condition of the illumination, the air pollution, and the biotas. This museum library requires expert librarians to optimize efforts to preserve the library heritages. From expert librarians, it is hoped that library management can improve the quality of the library. Expert librarians are also expected to be able to understand disaster literacy so that they can find out the efforts that need to be taken when a disaster occurs for the safety reasons of staff, visitors, and library collections.

\section{REFERENCES}


Badan Standardisasi Nasional Indonesia. (2019). Standar Nasional Indonesia. Diambil kembali dari Badan Standardisasi Nasional Indonesia: http://sispk.bsn.go.id/SNI

Fatmawati, E. (2017). Identifikasi Faktor-faktor Penyebab Kerusakan Koleksi Perpustakaan. Jurnal Edulib, 7(2), 108-119.

Fatmawati, E. (2018, Juni). Preservasi, Konservasi, dan Restorasi Bahan Perpustakaan. Jurnal LIBRIA, 10(1), 13-32.

Kamus Besar Bahasa Indonesia, (2016) (Kementerian Pendidikan dan Kebudayaan Republik Indonesia). https://kbbi.kemdikbud.go.id/

Museum Konferensi Asia Afrika. (t.thn.). Diambil kembali dari Museum Konferensi Asia Afrika: http://asianafricanmuseum.org/?lang=id

Rahardjo, M. (2010, Juni 1). Jenis dan Metode Penelitian Kualitatif. Diambil kembali dari UIN Maulana Malik Ibrahim Malang: https://www.uin-malang.ac.id/r/100601/jenis-danmetode-penelitian-kualitatif.html

Undang-Undang Republik Indonesia Noomor 43 Tahun 2007 Tentang Perpustakaan. 